Katarzyna Blakiewicz'

Uniwersytet Warmińsko-Mazurski w Olsztynie, Polska

Wydział Teologii

Maksym Adam Kopiec ${ }^{2}$

Pontificia Università Antonianum, Roma, Italia

Facoltà di Teologia

\title{
Conscience in the light of the Truth and the light of the Good in the context of the necessary correlation of religious studies and natural sciences
}

\section{Introduction}

The study of human conscience falls within the scope of the humanities. It focuses on the axiological plane of human activity and, in this sense, provides a common foundation for the natural sciences and the humanities. ${ }^{3}$ The study of

\footnotetext{
${ }^{1}$ Associate professor doctor of theology Katarzyna Blakiewicz - dogmatist, head of the department of Fundamental, Dogmatic and Moral Theology at the Faculty of Theology of the University of Warmia and Mazury in Olsztyn. Main research areas: theology of dialogue, historiological theology, hagiology, Mariology. More important publications: Dialog jako metoda ewangelizacji wspótczesnego świata wedlug Jana Pawła II (Olsztyn 2000); Development of the Eve-Mary Antithesis since the Catechism of the Council of Trent until the Catechism of the Catholic Church (1566-1992) (Olsztyn 2013); Teologia historiozbawcza w dogmatyce polskiej XX wieku (Olsztyn 2010); Teologia dialogu (Olsztyn 2016), Teologia objawień Maryjnych w Gietrzwałdzie (Olsztyn 2019); e-mail: kaparz@uwm.edu.pl. ORCID: 0000-0002-7965-9064.

2 Associate professor of theology Maksym Adam Kopiec OFM - fundamental theologian, research and didactic employee of the Pontifical University Antonianum in Rome (2004-2019). Main research directions: theological and fundamental foundations of interdisciplinary research, credibility of Christian revelation in interdisciplinary dialogue and taking into account the issues of theology of religion, anthropological context of evangelization, religious humanism. More important publications: Il Logos della fede. Tra ragione, rivelazione e linguaggio (Roma 2014); L'evangelizzazione nel recente magistero dei papi. Tra le sfide, il mandato e la carità (Terni 2016); Il cristianesimo e le religioni. Verso un inclusivismo cristologico-trinitario (Roma 2016); Umanesimi laici e il cristianesimo umanistico. La missione profetica, apologetica e dialogica della teologia (Roma 2017); Non abbiate paura della Verità! Giovanni Paolo II e la Veritatis splendor (Hong Kong 2018); e-mail: maksymk@libero.it. ORCID: 0000-0002-1055-6251.

${ }^{3}$ I.G. Barbour, Religion and Science. Historical and Contemporary Issues. A Revised and Expanded Edition of Religion in an Age of Science, London 1998.
} 
human conscience concerns itself with the human action - activity taken by the human being in relation to their surrounding reality, evincing their sensibility to the system of values. Defining and delimiting the common scope of the humanities, natural sciences, economic sciences, and economy is important in the context of introducing innovations in undertakings aimed at multiplying and improving material goods, as well as their economic use, and simultaneously destined to strengthen and perfect the humanity of the individuals and communities they create. ${ }^{4}$ Economics and economy focus on the category of the action, whereas the humanities - on the category of the person. Both categories are closely interrelated, as demonstrated by Karol Wojtyła in his book The Acting Person (first edition: 1969), ${ }^{5}$ and then further discussed in the papal teachings of John Paul II, particularly in Veritatis splendor (1993). ${ }^{6}$ The action manifests itself as creative dynamism whereby the person expresses his relation to the Truth and the Good. ${ }^{7}$

In this paper, the authors explain the dependence of actions - including ventures taken to alleviate social and economic needs - on axiological factors determining subjective activity proper to a human person. In the course of this activity, there is a correlation between the action and the hierarchy of values in a single-person centre delimited by the theological notion of conscience. Humanistic explorations are conducted on the plane of anthropological research, following a method characteristic of fundamental theology, with consideration of philosophical and ethical aspects. ${ }^{8}$ Conclusions drawn upon analysing the subject matter and the sources, point to the value of 'the human conscience' as a singleperson space, not only related to religious life but also essential for the quality of effects produced by the pragmatic activity involving various dimensions of social life: cultural, political and economic.

\section{Conscience as a humanistic issue important for science, economy, and society}

One should ask: what does, and what should, determine social and economic priorities in internal policies of different states and nations? The economic dynamics of most states are driven by the goal defined as multiplication of material

${ }^{4}$ M.P. Gallagher, Fede e cultura. Un rapporto cruciale e conflittuale, Milano 1999.

${ }^{5}$ K. Wojtyła, Osoba i czyn [in:] Osoba i czyn i inne studia antropologiczne, red. T. Styczeń et al., Lublin $1994^{3}$.

6 John Paul II, Encyclical letter "Veritatis splendor" (1993), Vatican 1993 [= VS].

7 The capitalisation of the words 'Truth' and 'Good' in the paper results from the necessity to indicate their sense, differing from the usual meaning of the words 'truth' and 'good' written in lowercase.

${ }^{8}$ D. Lambert, Scienze e teologia figure di un dialogo, Roma 2006. 
goods. This goal governs all political decisions made by the managing bodies. However, at the opposite pole of economic dynamism are the intentions of the subject who selects the goal and the methods leading to its achievement. The intention emerges in the single-person (individual) subject. It is the cause which initiates the dynamics of activity, or action. Theological language knows the notion of 'conscience' which signifies a place in the human person - the subject who manages the decision-inspiring motives and who creates the intentions based on the adopted hierarchy of values. ${ }^{9}$

The enduring, unbroken topicality of the 'human conscience' issue, not only in theology but also in every man's life, is beyond dispute. It seems unlikely, or impossible, to find a man who does not ponder over the fundamental questions about the beginning, the goal and the value of his own life, as well as the possibility of a new life after death. Some of those questions concern the adoption of a certain lifestyle, the manner of using one's freedom and a set of criteria for making fundamental decisions which lead to definite single-person actions. Priority actions include those involving morality, i.e. those subject to evaluation in terms of ethics. Such definite actions are more than an external sheath through which the person is perceived by others; they express and simultaneously determine the deepest layers of spirituality and being. Significantly, in doing so they remain coherent with the inner life, the self-awareness and the sense of identity of the person.

The ability to perform moral actions is unique to humans; performing them reveals the single-person nature of man as a free and responsible being. ${ }^{10}$ Therefore, ontologically, this ability is an inextricable part of the nature of human existence. Moral significance and value for every man are expressed in the Evangelical question: 'Good teacher, [...] what must I do to inherit eternal life?' (cf. Mark 10:17). The question does not refer to 'being' (esse) or the degree and quality of 'knowing' (cognoscere) but to 'acting' (facere). This perspective reveals the issue of acting which has consequences of eternal value, decisive for the final destiny of man: 'the relationship clearly indicated in the divine commandments, between the moral good of human acts and eternal life; Christian discipleship, which opens up before man the perspective of perfect love'. ${ }^{11}$

9 Catechism of the Catholic Church (1992), No. 1777-1779, New York-London-TorontoSydney-Auckland 1994.

${ }_{10}$ See the Polish sources of the universalist personalism according to Czesław Stanisław Bartnik, passim.

${ }^{11}$ VS 28. 


\section{The light of the Truth and the truth of a message}

The light of the Truth is a term which requires an understanding of the difference between 'truth' and 'the Truth'.

The term 'truth', written in lowercase, signifies a property of the message, communicated from a sender to a recipient and referring to some aspect of intelligible reality perceptible to human senses. Communicated truth, referring to an excerpt of reality, points to the harmony - complementarity - between one's current state of knowledge and one's message to another. It is managed by the single-person subject acting out of his intention to share the cognitive content: thought, information. The effect of the communicated truth may be observed as a link established between the communicating and the receiving parties.

The capitalised 'the Truth' points to a single, absolute reality which has a supernatural dimension. The term is not tantamount to 'truths', or versions of information communicated through various signs, referring to excerpts of the surrounding reality which is relevant to human being himself and his interpersonal relations. Man may experience only the splendor/brightness - 'light' of the Truth and read the full truth about himself in its radiance.

In the light of the Truth, the subject becomes aware of the existence of the Absolute which provides foundation for all creation, every excerpt of reality. A human person may experience the Truth in the form of 'light', which is an instance of the Absolute imparting itself, revealing itself, 'descending'. The single-person subject is incapable of managing the Truth for it is a person-related and not an object-related category. Object-related truth, understood as a message pointing to something specific, providing information, or as knowledge on a certain object acquired through the intellect or empirical experience, is always limited to the immanent dimension of reality. In contrast, subject-related truth is an interpersonal occurrence. It involves opening of the subject to another, who agrees to being studied as a gift - the gift of revealing of the truth about oneself. This kind of truth is open to the meta-empirical, meta-historical, or in other words: transcendental dimension of existence. Thus, it is a foregone conclusion that to speak of subject-related truth, it has to be accepted as a gift of revelation to another, of presenting oneself and one's subjective identity. In the case of God, only in this manner human being may accept the Absolute Truth tantamount to the Person of God.

Man needs to differentiate between 'the Truth' and 'truth' in order to establish the right hierarchy of values - a system of ordered priorities necessary for the person to perform an action in the form of work, culture, civilisation, organised community of people. Lack of a clear distinction results in the mistake of objectifying a person. The consequences of this mistake are apparent in the organisation of economy, state, law, etc. as social gaps, unequal treatment of people, national, 
ethnic, and professional groups and multifaceted chauvinism (e.g. in private, professional and social relationships in the national, regional and religious aspect).

\section{The light of the Good in the acting person}

Human behaviour is based not solely on the Truth but also on 'the Good', which should be understood as an absolute value, i.e. in the existential aspect. In the axiological category, 'the Good' should be considered also in the functional aspect, which signifies an exemplification of the intentions of the single-person subject in his activity. Correspondingly to the explanations referring to the light of the Truth, it may be said that a human person, as the author of the action, is in the light of the Good which provides human works with a new value. Human work may be considered 'good' only if it is connected with the Absolute Good as the source of multiplied quality of being. ${ }^{12}$

Karol Wojtyła, in his book The Acting Person explains the dependence of the action on the person and vice versa. According to Wojtyła, people's choices point to their single-person activity which has two perspectives: object- and subjectrelated. ${ }^{13}$

Object-related perspective refers to the goal which human being intends and strives to achieve. It grants the status of a creator or an author to a human person. Therefore, its character is personalistic or, to give a more precise semantic meaning: prosopoidal. ${ }^{14}$

Subject-related perspective is the foundation on which the human person bases all practical steps to the chosen goal. This perspective is always axiological in character, built on the priorities constituting the hierarchy of values implemented in the person's life. One should discern two hierarchies of values: theocentric and anthropocentric. ${ }^{15}$ The former rests on the priorities arising from the acknowledgment of God's existence and His self-revelation. The latter focuses on man as

${ }^{12}$ A. Briguglia, G. Savagnone, Scienza e fede. La pazienza del dialogo, Torino 2010.

${ }^{13}$ K. Wojtyła, Osoba i czyn, I 4, p. 90.

14 The term personalistic (derived from the Latin word persona, which signifies a person), known to a wide group of researchers, is associated with an organised philosophical reflection, a philosophical system. In turn, the term prosopoidal (derived from the Greek word prosopon, which signifies a person) is less common in the literature. Prof. C.S. Bartnik - from the John Paul II Catholic University of Lublin in Poland - suggests using the latter term in reference to the existential sense of the person, of one's growth and maturity in the axiological dimension (C.S. Bartnik, Dogmatyka katolicka, vol. 1, Lublin 1999, p. 373).

${ }^{15}$ K. Parzych-Blakiewicz, Aksjologiczna zasada dialogu matżeńskiego wobec przemian koncepcji matżeństwa [in:] Idea gender jako wyzwanie dla teologii, red. A. Jucewicz, M. Machinek, Olsztyn 2009, p. 128-129. 
the final creator of the surrounding reality and the legislator, thus eliminating or downplaying the divine paradigm. ${ }^{16}$

In the light of Karol Wojtyła's thought on the model of single-person dynamics of a human subject, the growth and maturity of the person rest on the axiological property of his actions. The quality of the person's existence hinges on the actions performed..$^{17}$ The action is an intentional manifestation of the hierarchy of values adopted by the person in his behaviour. Wojtyła points to the Good as the paramount value determining the durability and humanistic quality of the effects produced by human actions. The person refers to those paramount values and becomes 'fulfilled' in the single-person dimension. For only the person makes choices inspired by the intention recognised in the depths of one's own being. The intention of the acting person may reflect the Good or contradict those fundamental values. Correlation with the values of those two axiological categories of absolute value determines the quality of existential fulfilment of the human person as the action's author. In the light of the developed anthropological and personalistic thread in the thought of Karol Wojtyła / John Paul II, it may be asserted that a human person is capable of perceiving the light of the Good which manifests itself in the multiplied quality of actions. This process involves the fulfilment of the person's subjective activity aimed at the Good - in other words, at the absolute state of values exemplified by the action. Subjective activity of the human person in relation to his environment, leading to a transformation of this environment in accordance with the light of the Good, plays an intermediary role in the fulfilment of the absolute dimension of values in all excerpts of reality. This fulfilment manifests itself in the effects produced by human actions. The clearer the reference of the human author to the Good, the higher the existential quality of the actions. The dependence between the person and the action, explained by Karol Wojtyła, points to a pragmatic rule which stipulates that when the person, as the action's author, considers the light of the Good, the quality of effects produced by his actions in the category of goodness is multiplied.

Opposed to the fulfilment of the light of the Good in actions is the situation when the person refrains from making any reference to the Absolute dimension of those values. According to Wojtyła, this case also results in the immanent change in the quality of the human person, who is fulfilled but - in opposition to the only Good which ensures true fulfilment - in 'unfulfilment' ${ }^{18}$ The actions of such a person cannot be classed as good; in practice, they turn out to be existentially erroneous and morally wrong. This situation is described by Joseph Ratzinger / Benedict XVI who points to the afflictions of political systems which involved an isolation from the Absolute Good.

\footnotetext{
16 P. Lakeland, Postmodernity. Christian Identity in a Fragmented Age, Minneapolis 1997.

17 K. Wojtyła, Osoba i czyn, IV 2, p. 197.

${ }^{18}$ Ibidem, IV 2, p. 197-198.
} 


\section{Threat indicated in Veritatis splendor}

John Paul II, in the encyclical entitled Veritatis splendor, presents ethical activity as oriented at eternity - not in its abstract sense, but a definite, real sense of the Supreme and Absolute Good wherein man was formed and whereto he was summoned as to the ultimate goal. The Absolute Good implies an active consciousness based on the intellect, freedom and responsibility of the person as a being open to ethical instructions and values resulting from the Divine Revelation which is fulfilled throughout history by way of the laws of nature / the natural order. ${ }^{19}$ The Absolute Good leads to the Creator as the Father in whom a human person finds full happiness and ultimate fulfilment: 'the One who «alone is good» and who, by giving himself to man in Christ, offers him the happiness of divine life'.$^{20}$ This indispensable openness is only possible if preceded by the grace and the gift of the Holy Spirit residing in the heart of man.

At first glance, from the viewpoint of ecclesiastical teachings based on the Scripture and the Holy Tradition in the whole life and history of the Church, the topic seems clear and straightforward to regular parishioners. However, philosophy and religion, together with an array of intellectual currents, based on strictly theoretical assumptions, or so-called pastoral experience, are more and more inclined to question or modify the so-called existent moral values, incontrovertible and safe from all negotiations or human conventions, as asserted by John Paul II: 'At the same time, however [...] there have developed certain interpretations of Christian morality which are not consistent with «sound teaching» (2 Tim 4:3)'. ${ }^{21}$

Such tendencies in contemporary theological and moral thought are discussed in the encyclical which lists several most important trends. Nevertheless, their determinant and, at the same time, their common denominator is the relation between the freedom of man and the law of God, set forth by the Creator and thus providing the foundation of the natural law. This common denominator is such subjectivism and autonomy which would provide the human freedom - in ethical matters - with the prerogatives which do not appertain to it de iure and de facto prove harmful: 'Despite their variety, these tendencies are at one in lessening or even denying the dependence of freedom on truth'.$^{22}$ Those trends manifest an apotheosis of human autonomy and the human power to make decisions for oneself, which need affirmation and protection against the unconditional surrender to God and the acceptance of people's dependence on Him: 'Hence obedience to God is not, as some would believe, a heteronomy, as if the moral life were

\footnotetext{
19 Catechism..., No. 356.

${ }^{20}$ VS 29.

${ }^{21}$ VS 29.

22 VS 34.
} 
subject to the will of something all-powerful, absolute, extraneous to man and intolerant of his freedom' ${ }^{23}$

An extreme form of this style of thinking may be found in views typical for the existentialism of the first half of the $20^{\text {th }}$ century. From the emergence of the Nietzschean thought onwards, this reflection could inform theology, imbuing it with a certain sensitivity, or perhaps also a trepidation in the face of the Divine Order pervading creation and conceivably jeopardising human autonomy. Such a concern is voiced by J.P. Sartre, who asserts that the very existence of God makes human autonomy impossible. ${ }^{24}$

To invoke the teachings of the Second Vatican Council, recorded in the Constitution Gaudium et spes, ${ }^{25}$ the relationship between destructive philosophical ideas and social realities has exerted manifest impact also in the field of theology, as exemplified by, among others, the false concept of autonomy stipulating that 'created things are not dependent on God and that man can use them without reference to their Creator'. ${ }^{26}$ Such a concept, when adopted by man, causes gradual atheisation and finally results in definitive exclusion of God from the human space of existence and living. In contrast, basing on Gaudium et spes,${ }^{27}$ the Pope asserts that: 'Without its Creator the creature simply disappears... If God is ignored the creature itself is impoverished' ${ }^{28}$ Thus, he points to the threat of progressive self-alienation of man. In other words: without God, man profoundly downgrades the value of his own humanity, cuts the roots of his identity, loses his dignity, and draws away from his ultimate destiny. Paradoxically, by resolving to build himself using his own abilities and adhering to his own plans, he lapses into a new kind of heteronomy: addiction to illusions and passage into an unreal world of projections. ${ }^{29} \mathrm{He}$ falls into the abyss of nothingness, becoming the victim and the external manifestation of nihilism.

Despite the knowledge of the effects produced by disrupting the harmony between the person's world and the world of values, contemporary theology evinces a tendency to relativise the Truth, both in the doctrinal and the moral dimension. With regard to conscience, theology points to its deformation which prevents

${ }^{23}$ VS 41.

24 J.P. Sartre, La Nausea, trad. B. Fonzi, Milano 1966, p. 178-184.

${ }_{25}$ Vatican Council II, Pastoral Constitution on the Church in the Modern World "Gaudium et spes" (1965), No. 36, [online] http://www.vatican.va/archive/hist_councils/ii_vatican_council/ documents/vat-ii_cons_19651207_gaudium-et-spes_en.html [20.04.2018][=GS].

26 VS 39.

27 GS 36.

28 VS 39.

29 Z. Kunicki, Mocne nadzieje i płonne obietnice. Wokót krytyki iluzji politycznych [in:] Zbawienie w nadziei. Wokół encykliki „Spe salvi” Benedykta XVI, red. K. Parzych-Blakiewicz, Olsztyn 2010, p. 25-33. 
man from accessing its sacral nature. The sacredness of conscience is a prerequisite for human openness to the light of the Truth and acceptance of the Absolute Truth and the Revealed Law of God in salvation history and natural moral order arising from the divine act of creation.

Meanwhile, the response to the crisis in affirming the Truth and the crisis of conscience, provided in Veritatis splendor, remains as valid as ever:

But temptations can be overcome, sins can be avoided, because together with the commandments the Lord gives us the possibility of keeping them: 'His eyes are on those who fear him, and he knows every deed of man. He has not commanded any one to be ungodly, and he has not given any one permission to sin' (Sir 15:19-20). Keeping God's law in particular situations can be difficult, extremely difficult, but it is never impossible. ${ }^{30}$

The ability to know, accept as one's own, and implement the Law of God - according to biblical sources and theological studies - is inscribed in the perpetual plan of creation and salvation of man and all existent beings. In this perspective, the invoked teachings of the Second Vatican Council gain special importance, stipulating as follows: 'supreme rule of life is the divine law itself, the eternal, objective and universal law by which God out of his wisdom and love arranges, directs and governs the whole world and the paths of the human community'. ${ }^{31}$

The central figure in God's plan is man, an active participant therein: '... and hence man is able under the gentle guidance of God's providence increasingly to recognize the unchanging truth' ${ }^{32}$ This fact illustrates the immense dignity granted to man when God made him co-responsible for the world, history, himself, and others. The measure of this dignity and the beauty of human existence are the gifts of intellect and freedom which, in man's conscience, give him the ability of recognition in the area of the Truth and decision-making in the area of the Law.

The words of John Henry Newman, quoted in the encyclical: 'Conscience has its rights because it has its duties' ${ }^{33}$ should also be interpreted in this vein. This right and privilege retained only and exclusively by a human person should not be associated, let alone equated, with any attempt at defining what is true and what is false, or deciding what is morally right or wrong. Man is able to cheat his own

30 VS 102.

31 Vatican Council II, Declaration on Religious Freedom “Dignitatis humanae”, (1965), No. 3, [online] http://www.vatican.va/archive/hist_councils/ii_vatican_council/documents/vatii_decl 19651207 dignitatis-humanae en.html [20.04.2018] [= DH]; VS 43.

32 DH 3; VS 43 .

33 J.H. Newmann, A Letter Addressed to His Grace the Duke of Norfolk: Certain Difficulties Felt by Anglicans in Catholic Teaching, Uniform Edition: Longman, Green and Company, vol. 2, London 1868-1881, p. 250. 
conscience but if he accepts - as his own - the words of Saint Paul: 'the requirements of the law are written on their hearts, their consciences' (Rom. 2:15), the Truth will reside in his conscience which will make his life, by the virtue of the Holy Spirit, a reflection of the unchangeable and universal Law of God.

\section{The true freedom: autonomy in theonomy}

As Joseph Ratzinger once observed, the term 'autonomy', used consistently and coherently by Immanuel Kant in opposition to 'heteronomy', was not accepted and assimilated into theological speculations and debates in the postconciliar period in the vein wherein the Council wanted to present it in the form of the relevant Magisterium. Those discussions lost the depth and the linearity of Kant's thought, which either way could never be reconciled with the unfathomable Christological vision whose goal, in opposition to Kant's, is not a norm but a living person of the Resurrected One in the Evangelical memory on the event of Jesus ${ }^{34}$ - memoria Jesu. ${ }^{35}$

In reference to the autonomy of conscience, discussed in Veritatis splendor, Ratzinger asks the following question: what is the correct concept of autonomy, fully harmonious with the Christian vision of man? The first thing to be emphasised is the certitude and the patency that man did not create himself and did not grant himself his existence: man is part of creation, a unique gift of the Divine Benefactor and the Maker of the existence of men and other beings which constitute the entire reality surrounding humans. By refusing to accept the truth of his creaturely nature, which sets him free, man radically reduces the understanding of himself, regarding himself only as a regular product of created nature which, as such, is devoid of freedom. Consequently, man treats himself as any other being of animalistic nature. Thus, such thinking transforms the fundamental rule of modern democratic culture which, metaphysically, used to stipulate the necessity to centre on the human being, on all people, and their freedom. In the context of illuminism and its emancipatory ideas, it is not God who determines man, the world and the axiological conditions of a person's actions. Conversely, according to the Bible, man is a creature who exists and lives in dependence on God, who participates in the divine life thanks to God's merciful love: this participation is a shared love in love. If love was to be defined as dependence, let us note that love is essentially superior to dependence. Love reveals that it is precisely this relationality that constitutes the true form of

${ }^{34}$ Benedetto XVI, Fede, ragione, verita'e amore, Lindau-Torino 2009, p. 565-577.

${ }_{35}$ P. Sequeri, Memoria fidei: il dinamismo dell'atto di fede (memoria, evento e profezia) [in:] Pontificio Consiglio per la Promozione della Nuova Evangelizzazione, [online] http://www.pcpne. $\mathrm{va} /$ content/nvev/it/Dicastero/convegniIncontri/congresso-internazionale-di-catechesi/relazioniCIC2013/Sequeri-relazione3.pdf [9.03.2018]. 
participation in the Absolute and the Trinitarian Being. Therefore, life in communion with God, discovering one's own story in His Light, recognising in Him the Way, the Truth, and the Life, is not perceived by man as isolation or alienation; it does not involve a heteronomy but a process of truly finding oneself in one's authentic identity as the gift of oneself received from the Divine Benefactor. Saint Augustine teaches that God is intimior meo and that - by obedience and remaining in full union with God in Christ - man does not renounce himself, abandon himself, lapse into any heteronomy, or fall into a servile dependence which could never be accepted. To the contrary, it is precisely in that way that man finds his own intimacy, his own single-person identity, thus confined in the sin of lonely selfreference, which is a manifestation of the spiritual state of hell:

If in fact a heteronomy of morality were to mean a denial of man's self-determination or the imposition of norms unrelated to his good, this would be in contradiction to the Revelation of the Covenant and of the redemptive Incarnation. Such a heteronomy would be nothing but a form of alienation, contrary to divine wisdom and to the dignity of the human person. ${ }^{36}$

In accordance with the biblical concept of the human being, by joining with Christ, man finds himself and, by connecting with his inner self, finds God and finds his theosis, his true essence and true autonomy. Precisely by rejecting the individualistic self-determinism, man discovers the intimacy of his own existence as a gift received from God, by the agency of Christ and in communion with Him. In this manner, man becomes himself, and upon finding an authentic union with God, he achieves real freedom open to accepting love, to becoming both loved and capable of love. In this sense, also the notion of freedom, which occupies a central place in the Scripture and in the debate with modernity, must be placed within the Christological perspective of humanity. Man is free not when he guards himself against God or stands opposed to God but when he accepts Him and enters in the relation of union with Him by the agency of Jesus as the Messiah. Human freedom is always shared and only as such it may incessantly grow in man. Maintaining freedom is possible upon opening the human freedom to the Absolute Freedom of God which summons but never by force. ${ }^{37}$

According to theological research, conscience enjoys full autonomy and freedom when it is rooted in God. Man, together with his conscience, is free and autonomous insofar as he is immersed in theonomy. True autonomy and

36 VS 41.

${ }^{37}$ Esistono verità morali assolute?, CulturaCattolica.it, [online] https://www.culturacattolica. it/cristianesimo/teologia/esistono-verit\%C3\%A0-morali-assolute [28.04.2017]; Benedetto XVI, Fede..., p. 565-577. 
true freedom become fulfilled in the absolute autonomy and freedom of God. By participating in the absolute freedom and infinite autonomy of God, human freedom - which delimits the dynamics of the autonomy of conscience - becomes fulfilled in its orientation at excellence, whereto the human person is invited by God.

\section{Conclusions}

The dependence of action on axiological factors determining subjective activity is focused on the existential/ontic dimension of a person. In this context, an action is understood as an effect produced by the involvement of values in the creative activity by the person. Hence, an action reveals the person's intentions formed in his conscience, which is the single-person centre where the person evaluates his actions in terms of their consistency with the adopted hierarchy of values. Anthropological research based on the personalistic anthropology of Karol Wojtyła / John Paul II has demonstrated that a person, as a subject engaging in creative activity, is dependent on the Absolute Truth and Good. Further exploration of the dependence of the action on the axiological dimension of reality has led to the conclusion that the Truth and the Good manifest themselves in actions, but only in the form of 'light' whereof the Absolute is the source.

It should be asserted that human action occurs in the light of the Good and the light of the Truth. This light is not tantamount to an emanation of being or energy, it is not an aspect of reality affected by the action. However, the light creates the category of ascribing ethical value to the action, which focuses largely on the phenomenon of man, as a person subject to the law of maturity in existential/ ontic 'fulfilment'. The light of the Good and the light of the Truth manifest themselves in the action which is produced by a person and constitutes the elements and modules of the environment: household, culture, civilisation, economy, legislation, communities. In this context, the light of the Good and the light of the Truth are presented as a principle of forming intentions which precede all kinds of human actions. This principle, developed in the framework of theological and fundamental research, is beneficial for society as it implies a 'new' anthropology and the resulting 'new' humanism concerned with harmony between the common good and the individual good. This new humanism provides a foundation for establishing justice in social relationships, which leads to better effects of cooperation between citizens who engage in various private and professional relationships. Therefore, the creative activity of a human person, in all organisational spheres of social and economic life, should be perfected in the perspective of the light of the Good and the light of the Truth. 
John Paul II indicated in Veritatis splendor the threats to the quality of individual and social life, caused by the lack of affirmation for the Absolute Truth. Indeed, a human person, as an autonomous subject, can create and can make moral decisions independently and arbitrarily, with no reference to the Truth. Adopting such an ethical principium inevitably leads to subjectivism and relativism which overturn the primacy of the objective, universal, and transcendental Truth. As discussed in this paper, radical moral individualism is closely related to the experience of existential void and to the lapse into nihilism. Indubitably, such foundations of single-person activity have negative and harmful repercussions for the creation of a healthy and just social order, as they lead to the disruption of harmony between the sphere of the person's life and the sphere of effects produced by the person's subjective activity. The proportions of the Truth and truth are upset, resulting in the dominance of the object over the subject. Relinquishing the principle of the light of the Truth impacts social and economic structures, which may be observed in the subjugation of a single-person being to things.

Employing the light of the Good and the light of the Truth in interpersonal relations requires freedom at the level of subjective autonomy. The required conditions are created by 'conscience' which involves the most intimate sphere of human persons, where the subject becomes confronted with the recognised system of values. Subjectivity of a person signifies the ability to autonomously make decisions concerning self-revelation to others. The activity of the person in the subjective sphere occurs in conscious reference to the system of values based on the Truth and the Good in the category of the Absolute - the Perfect Fullness.

\section{Autonomia sumienia w blasku Prawdy i blasku Dobra w świetle potrzeby korelacji nauk ścisłych i humanistycznych}

\section{Streszczenie}

Artykuł dotyczy zagadnienia korelacji prawdy i dobra w ludzkiej aktywności. Autorzy wskazują sumienie jako subiektywne centrum, w którym osoba ludzka weryfikuje swoją pozycję w relacji do Absolutu jako źródła wartości, włączając absolutną Prawdę i Dobro. Odróżniają prawdę od Prawdy i dobro od Dobra, wyjaśniając różnicę: dobro i prawda odnoszą się do fragmentu rzeczywistości ludzkiej, środowiska i ludzkiej aktywności twórczej; Dobro i Prawda odnoszą się do absolutnej kategorii wartości jako fundamentu etycznej weryfikacji działań osoby. Analiza jest oparta na personalistycznej antropologii Karola Wojtyły / Jana Pawła II — autora teorii zależności jakości bytu osobowego od moralnej jakości czynu osoby jako autonomicznego podmiotu, który działa w 'blasku’/jasności/świetle Dobra i Prawdy. Pokazują skutki zakłócenia harmonii między światem osoby i światem wartości, dotykające jakości struktur społecznych i ekonomicznych. 


\section{Słowa kluczowe}

Karol Wojtyła, Veritatis splendor, Osoba i czyn, ludzka aktywność, aksjologia, system wartości, religia dla nauki

\section{Keywords}

Karol Wojtyła, Veritatis splendor, The Acting Person, human activity, axiology, the system of values, religion for science

\section{Bibliography}

Barbour I.G., Religion and Science. Historical and Contemporary Issues. A Revised and Expanded Edition of Religion in an Age of Science, London 1998.

Bartnik C.S., Dogmatyka katolicka, vol. 1, Lublin 1999.

Benedetto XVI, Fede, ragione, verita' e amore, Lindau-Torino 2009.

Briguglia A., Savagnone G., Scienza e fede. La pazienza del dialogo, Torino 2010.

Catechism of the Catholic Church (1992), New York-London-Toronto-Sydney-Auckland 1994.

Esistono verità morali assolute?, CulturaCattolica.it, https://www.culturacattolica.it/ cristianesimo/teologia/esistono-verit\%C3\%A0-morali-assolute [access: 28.04.2017].

Gallagher M.P., Fede e cultura. Un rapporto cruciale e conflittuale, Milano 1999.

John Paul II, Encyclical letter "Veritatis splendor” (1993), Vatican 1993.

Kunicki Z., Mocne nadzieje i płonne obietnice. Wokół krytyki iluzji politycznych [in:] Zbawienie w nadziei. Wokót encykliki „Spe salvi” Benedykta XVI, red. K. Parzych-Blakiewicz, Olsztyn 2010, p. 25-33.

Lakeland P., Postmodernity. Christian Identity in a Fragmented Age, Minneapolis 1997.

Lambert D., Scienze e teologia figure di un dialogo, Roma 2006.

Newmann J., A Letter Addressed to His Grace the Duke of Norfolk: Certain Difficulties Felt by Anglicans in Catholic Teaching, Uniform Edition: Longman, Green and Company, vol. 2, London 1868-1881.

Parzych-Blakiewicz K., Aksjologiczna zasada dialogu matżeńskiego wobec przemian koncepcji matzeństwa [in:] Idea gender jako wyzwanie dla teologii, red. A. Jucewicz, M. Machinek, Olsztyn 2009, p. 127-140.

Sartre J.P., La Nausea, trad. B. Fonzi, Milano 1966.

Sequeri P., Memoria fidei: il dinamismo dell'atto di fede (memoria, evento e profezia) [in:] Pontificio Consiglio per la Promozione della Nuova Evangelizzazione, http:// www.pcpne.va/content/nvev/it/Dicastero/convegniIncontri/congresso-internazionale-di-catechesi/relazioni-CIC2013/Sequeri-relazione3.pdf [access: 9.03.2018]. 
Vatican Council II, Declaration on Religious Freedom "Dignitatis humanae" (1965), http://www.vatican.va/archive/hist_councils/ii_vatican_council/documents/vat-ii_ decl_19651207_dignitatis-humanae_en.html [access: 20.04.2018].

Vatican Council II, Pastoral Constitution on the Church in the Modern World "Gaudium et spes" (1965), http://www.vatican.va/archive/hist_councils/ii_vatican_council/documents/vat-ii_cons_19651207_gaudium-et-spes_en.html [access: 20.04.2018].

Wojtyła K., Osoba i czyn [in:] Osoba i czyn i inne studia antropologiczne, red. T. Styczeń, W. Chudy, J.W. Gładkowski, A. Rodziński, A. Szostek, Lublin $1994^{3}$. 